\title{
RESEARCH INTO LIVONIAN SYNTAX: THE RESULTS OF PREVIOUS STUDIES AND THE TASKS AHEAD
}

\author{
Miina Norvik \\ University of Tartu
}

\begin{abstract}
The objective of this article is to present the main findings of research into Livonian syntax. As is typical of the Finnic languages other than Estonian and Finnish, in the past, syntax-related issues have received little attention. For instance, the only scientific grammar of Livonian, which was written in German and published in the 19th century, remains the most comprehensive overview of Livonian syntax. In recent times, however, interest in syntax-related issues has grown and there are several separate studies on specific issues of Livonian syntax. Furthermore, a contemporary Livonian reference grammar will be published in a few years and it will also contain a chapter on syntax. The present article is meant to give a research overview of the main topics discussed previously and point out the main challenges for future research.
\end{abstract}

Keywords: Livonian, syntax, reference grammars, predicate, nominal arguments, clause types

DOI: http://dx.doi.org/10.12697/jeful.2016.7.1.08

\section{Research into Livonian syntax: the past and present}

Scientific study of Livonian began in the middle of the 19th century, when as a result of field work by A. J. Sjögren and F. J. Wiedemann, a Livonian grammar (1861a) and dictionary (1861b) were published. Although traditional descriptions of Finnic languages other than Estonian and Finnish tended to concentrate on phonetics, morphology, and derivation, this particular grammar also contains a chapter on syntax. In fact, it remains the most comprehensive scientific grammar of Livonian up to the present day, including with respect to syntax. The grammar overview written by L. Kettunen and published as part of the Livonian-German dictionary (1938) did not include a separate section on syntax. The grammar overview by T.-R. Viitso (2008) contains only a 5 page long overview of syntax (additionally, however, information on syntax-related matters can also be found in sections on morphology). 
Still, it should be noted that recently several separate studies on syntaxrelated topics have been published. The first of these is the dissertation by R. Grünthal (2003), in which he studied adpositional phrases in the Finnic languages, including Livonian. P. Kehayov et al. (2012) studied evidentiality. T.-R. Viitso (2014) discussed the expression of deontic modality. The expression of evidentiality and modality were also dealt with by B. Wälchli in a paper published in 2000. H. Metslang et al. (2015) recently published a paper on negation, and M. Norvik (2015a) published a doctoral dissertation on the expression of future time reference.

Thus, the current situation is one where there is only one scientific grammar of Livonian containing an overview of syntax with this grammar having been written more than 150 years ago and mainly directed toward an audience of 19th century German-speaking linguists. Although the book gives valuable insight into the Livonian language of that time, it does not enable one to get a full picture of the present-day language nor does it meet the needs of present-day researchers and language users. The syntax overview by Viitso (2008) and other individual studies on various topics do not cover the whole range of syntax-related issues. Therefore, there is an urgent need for a new reference grammar of Livonian, which would describe its modern form while taking into account contemporary approaches in linguistics. The preparations for publishing such a grammar began in January 2016 and are funded by the Hõimurahvaste programm (Kindred Peoples' Programme).

With regard to the tasks ahead in compiling the syntax sections of this new grammar, the objective of this article is to present and discuss the main results of previous work, which contain information on syntax. Although I mention some topics in this article that have received little attention or no attention at all in the past, the aim is not to present a final list of such topics. The possibility of Latvian influence is also discussed only in passing as this topic requires much further research; also, it should be noted that it is not always easy to tell, whether we are dealing with contact-induced change or parallel development. As will become apparent from this article, the main issues of Livonian syntax have been discussed at least to some extent in earlier work. However, this information is scattered among various sources (grammar overviews, separate studies) and across different sections of these sources (syntax and morphology). 
The linguistic examples used in this article come from various sources that originate from different periods. The original sources also contain different modes of transcription: there are transcribed texts as well as texts following the written standard of the Livonian literary language. For the sake of consistency, all examples in this article are presented following the conventions of the written standard. To achieve this goal only minor changes had to be made (mainly phonological in nature); the syntax was not affected. With regard to the new reference grammar, some of the challenges involved, such as the selection of the most representative examples and finding a balance between spoken and written language, will not be discussed in detail here.

This article proceeds as follows: the main grammatical functions are discussed in section 2, phrase structure in section 3, clause types and word order in section 4, and pragmatic meanings of sentences in section 5 .

\section{Grammatical functions}

\subsection{Predicate}

With regard to the predicate, the syntax-related topics that have been previously discussed mainly concern the temporal system (see subsection 2.1.1), mood/modality (2.1.2), and to a lesser extent also the expression of aspectual distinctions (2.1.3).

\subsubsection{Temporal system}

As typical of the Finnic languages in general, Livonian makes a morphological distinction between the past and present (the present being the unmarked form), e.g., ma mõtlõ $b$ (I think:1sG) 'I think' vs. ma mottliz (I think:PST.1SG) 'I thought'. For 1Sg (infrequently for 3Sg) the so-called eternal or atemporal forms also are found. These forms do not contain any personal endings and enable one to convey a continuous situation, e.g., ma mõttõl 'I think, I have a permanent thought', or mediate recollections, as in example (1) (see Viitso 2008: 319). By and large, the formation of present and past forms has been described more extensively than their actual usage, including secondary uses. 
(1) Ma nustā jālga i’lzõ, ma nǟ, ku mi'nnõn pizār I lift leg.GEN up I see that I:DAT bloodsucker um akkõn jālga jū'rõ. be.3SG stick:APP leg.GEN to

'I lifted my leg up and I saw that a bloodsucker had stuck to my leg.'

(Viitso 2008: 319)

A recent study by Norvik (2015a) brings into focus the expression of future time reference (FTR). This topic has received only scant attention in the past as there is no morphological future marker in Livonian; the means for conveying the FTR instead belong to the level of (morpho)syntax. In her study, Norvik primarily focuses on the verb lìdõ 'will be', which she argues a) to be obligatory in simple predicate clauses with FTR thereby constituting the future copula (example 2), and b) to form the future perfect -construction together with the active past participle (Norvik 2015a: 49-50, 58-59; for the future perfect, see also below). Although Sjögren and Wiedemann (1861a) claimed that the construction $\mathrm{NP}_{\text {Dat }}+$ līb (3Sg) + T-infinitive (e.g. min līb kuts 'I will call') could also be associated with the expression of temporal (future) meaning, Norvik shows that this construction was used in 19th century texts, but mostly with a modal (deontic) meaning. 20th century texts already contained very few examples of lìdõ in this construction (see more in Norvik 2015a: 56-58).

\section{(2) minā līb si’n päal ne'i kõ 'zzi \\ I will_be:1sG you.GeN on so angry \\ 'I will be so angry with you.' (Setälä 1953: 104)}

The common way to express FTR by means of using a verb in the present tense is pointed out in all three main overviews of Livonian grammar (Kettunen 1938, Sjögren and Wiedemann 1861a, Viitso 2008). The fact that the expression of FTR tends to involve the interplay of a verb in the present tense, accompanying bounders ${ }^{1}$, and the choice between object cases is, however, only briefly mentioned (see Norvik 2015a: 37). Example (3) illustrates the case where the verb occurs in the present tense, the verb particle jära $\bar{a}$ indicates completeness, and

1 Following J. Bybee and Ö. Dahl (1989: 85-86) and B. Wälchli (2001: 419), the term bounder is used as a cover term for verb particles and prefixes, which make the process denoted by the verb bounded or telic. 
the object appears in the genitive case. Their more precise interplay requires further research.

$$
\begin{aligned}
& \begin{array}{llllll}
\text { (3) tämā } & \text { kìtiz: } & \text { “ma } & \text { sieb } & \text { si’n } & \text { järāa” } \\
\text { s/he } & \text { say:PST.3SG } & \text { I } & \text { eat:1SG } & \text { you.GEN } & \text { away }
\end{array} \\
& \text { 'S/he said, "I will eat you".' (EDC) }
\end{aligned}
$$

The perfect and pluperfect forms are compound forms that consist of an auxiliary verb in its present or past form and an active or passive past participle. The possible auxiliaries (vōlda 'be', sōdo 'get; become', lìdõ 'will be') are treated somewhat differently with their usage explained to varying extents across different works. For example, in his grammar overview Kettunen (1938) introduces the auxiliary vólda 'be' + APP -constructions as representations of the perfect and pluperfect, see (4a) and (4b), respectively; examples of sōdo + PPP (5) are given in the section that describes the formation of the PPP; and lìdo + APP -forms are included with the potential perfect. It is only from the translations into German that their more exact usage can be understood. Viitso, in turn, refers to forms such as (4a) and (4b) as compound past forms and līdo + APP -forms (6) as compound future forms; sōdo + PPP -forms (5) are introduced with passive constructions (see Viitso 2008: 323-324).

(4) a. ma u'm andõn

I be.1sG give:APP

'I have given' (Kettunen 1938: LXIII)

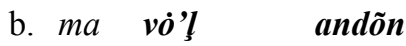
I be.PST.1SG give:APP
'I had given'

(5) ta sāg $\quad$ taptõd

$\mathrm{s} /$ he get:3sg kill:PPP

's/he will be killed' (Sjögren and Wiedemann 1861a: 159)

(6) Siz ta līb loptõn ilĭżskūol.

then s/he will_be:3sg finish:APP university.GeN

'Then s/he will have finished university.' (Viitso 2008: 323) 
The functions of sōdóllīd $\tilde{o}+\mathrm{APP} / \mathrm{PPP}$ have been discussed more thoroughly by Norvik (2015b). It is argued that līdo + APP deserves to be called the future perfect as its main function is to express anteriority in the future domain. Although in example (6) lìdõ + APP occurs in the main clause, it is shown in Norvik (2015b) to be more common in subordinate clauses. Furthermore, whereas in the subordinate clause one would expect a future marker to occur with a modal meaning, in the subordinate clause li $d \tilde{o}+$ APP is mainly found with a temporal (future) meaning (Norvik 2015b; cf. also Bybee et al. 1994: 274, Comrie 1993: $48,118)$.

Sjögren and Wiedemann (1861a: 145, 160) also associate the Futur Exactum (which is the same as the future perfect) with the sōdo + APP -constructions, although the construction is claimed to strongly express completeness. In the case of example (7), which contains the $s \bar{Q} d \tilde{o}$-verb as the main verb, Viitso (2008) also analyses the APP as a state adverbial. As shown by Norvik, the occurrence of sōdo + APP -constructions in texts (both in spoken as well as written language sources) is rare. Furthermore, it is suggested that due to their overlapping use with līdo + APP, the $s \bar{Q} d \tilde{o}+\mathrm{APP}$-constructions may have fallen out of use (see discussion in Norvik 2015b).

\section{(7) Ma sōb siest lēbast siend. \\ I get:1SG this:ELA bread:ELA eat:APP \\ 'I will get full from this bread.' (Viitso 2008: 323)}

In Finnic languages, a distinction is usually made between the so-called personal and impersonal voices, while Livonian is said to be an example of an active and passive distinction (Laanest 1975: 156-157). Whereas Viitso (2008: 324) categorises vólda + PPP and $s \bar{o} d \tilde{o}+$ PPP as passive constructions, Sjögren and Wiedemann (1861a) and Norvik (2015a) additionally regard līdõ + PPP -constructions to be passive constructions (example 8). The sōdo + PPP -construction is described as expressing an action and $v \bar{o} l d a+$ PPP a state (Viitso 2008: 324). The lìdõ + PPP -construction appears to go in line with vólda + PPP as it also tends to convey a state though one in the future (see Norvik 2015b). As indicated by Norvik (2015b), līdõ + PPP constructions are, however, rare in texts. 


\section{(8) līb touvis sidtõt \\ will_be:3SG heaven:INE bind:PPP \\ 'shall be bound in heaven' (ŪT 1942, Mt. 16: 19)}

Still, it is possible to speak about an impersonal meaning also for Livonian, which could be associated with instances where a 3Sg or 3Pl -form is used without a personal pronoun, as in example (9). The $3 \mathrm{Sg}$ -form denotes an inevitable or general action, whereas the $3 \mathrm{Pl}$-form is used for an optional or concrete action or for several actors (Viitso 2008: 321). Still, one can also observe variation, which may point to Latvian influence, as in Latvian there is no difference between $3 \mathrm{Sg}$ and $3 \mathrm{Pl}$ forms, e.g., in Latvian, nes 'carry' is used for both singular and plural third person forms. For a discussion of possible mutual influence in such zero person constructions in Latvian and Livonian, see A. Holvoet (2001: 385).

\section{(9) vietā kāndiz \\ water:PRT carry:PST.3SG \\ 'water was carried' (Viitso 2008: 321)}

As regards the choice between the passive and impersonal forms, Sjögren and Wiedemann (1861a: 159-160) point out that use of the zero person form is impossible if the sentence also contains an agentive adverbial. For instance, enţšs velsst (own.GEN brother:ELA) 'by his/her brother' could be inserted in example (5) but not in example (9).

\subsubsection{Mood and modality}

Modality is associated with the factual status of a proposition (Narrog 2012: 6, Palmer 2001: 1). A typical distinction in the field of modality is between epistemic, deontic, and dynamic modalities (de Haan 2006: 29). The category of mood is defined as expressing the modal value of the sentence by morphological means (Bybee et al. 1994: 176, and de Haan 2006: 33). For instance in Finnish (ISK 2004: 1510), the imperative and also jussive moods are associated with deontic modality, while the potential mood (and with some reservations also the conditional mood) are associated with epistemic modality. As the morphological marking of categories in Livonian has received much attention, the functions of mood categories have also been discussed in connection with their formation. 
The number of moods given for Livonian varies from author to author. For instance, Sjögren and Wiedemann (1861a) and Kettunen (1938) distinguish between the indicative, conditional, and imperative moods and show that an agent noun can be used with a quotative function. Viitso (2008), in turn, separates the jussive from the imperative mood, while treating the quotative as a separate mood, as well. In fact, Kettunen (1938) also introduces the potential mood, which is represented solely by līdõ used as a copula, and in a perfect construction (lìdo + APP). As no potential marker is preserved in Livonian (Laanest 1975: 155), Kettunen uses semantic reasons for his distinction. Furthermore, it should be noted that lìdõ can be found with a modal meaning conveying epistemic modality, though this is a secondary function (its primary function is to express the future as explained in subsection 2.1.1) (see also Norvik 2015a: 50-51, 59-60).

The conditional is described as the mood that speakers use to convey an opinion about a situation, which should or should not have occurred (10). The conditional is also found in contexts where it denotes a desired outcome or the necessity of a situation. The imperative is said to express a desire, an order or prohibition, or a call for a joint action. As is also the case in Estonian, the indicative form used without a personal pronoun is an alternative to using an imperative for 1Pl, e.g., vigõm (take:IMP:1PL) > vimõ (take:1PL) 'let's take'. In the religious literature of the 20th century, jussive forms also are found. The jussive is used for conveying a) obligation (11), b) concession, c) a desire or order for the hearer to mediate the original wish, order, or prohibition; these forms are accompanied by the particle $l a^{\prime} z$, as seen in examples (11) through (13). (Viitso 2008: 319-320)

(10) Ta võiks vīlda jõvā kuo'nnõ. $\mathrm{s} /$ he can:CND.3SG be:tINF already at_home 'S/he should be at home already.' (Viitso 2008: 319)

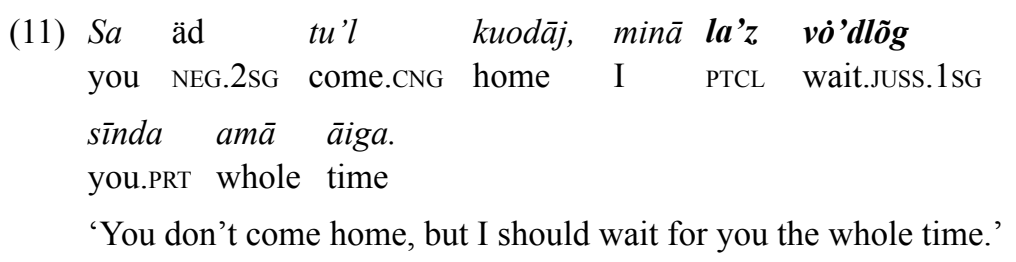

(Viitso 2008: 320) 
The use of the jussive in reported speech and commands (example 12) is discussed in a separate study by Kehayov et al. (2012), who also draw parallels between the expression of indirect commands and wishes in Estonian and Livonian. As they point out, where Livonian uses the jussive, Estonian typically uses the conditional mood (Kehayov et al. 2012: 50). Kehayov et al. (2011) show that the jussive forms in Livonian can also occur in deliberative questions ${ }^{2}$ (example 13); this reveals a parallel between Livonian, Latvian, and the Kihnu dialect of Estonian.

$$
\text { Åma kītiz, laz ma võtāg pūnda zēpõ. }
$$
mother tell:PST.3sG PTCL I take:JUSs.1sG twenty_pounds:PRT soap:PRT 'Mother told me to take a pound of soap.' (Kettunen 1925: 146)

$\begin{array}{llll}\text { (13) } & \text { Kui } \quad \text { sieda } & \text { laz } & \text { tīeg } \tilde{\boldsymbol{o}} ? \\ \text { how } & \text { this:PRT } & \text { PTCL } & \text { do:JUSS.3SG } \\ \text { 'How to do this?' } & \text { (Mägiste 2006: 154) }\end{array}$

The quotative can be given as a mood along with the other moods described above (see Krautmane 2010, Viitso 2008) or it can also be referred to as the means for expressing evidentiality, more precisely indirect evidentiality where information is acquired from another person (see Kehayov et al. 2012). This latter approach taken by Kehayov et al. (2012), enables them to also discuss the means (e.g., the perfect and pluperfect) used to express evidentiality as a secondary function. These are referred to as evidential strategies. Klaas-Lang and Norvik (2014: 600-603) also use the term evidentiality, when comparing the various ways for conveying evidentiality in the Baltic region.

Kehayov et al. (2012) distinguish between the reported indicative and the reported imperative (jussive). The main task of the reported indicative is to show that the speaker is only a mediator and not responsible for the message, see example (14). As further explained, the form can be used to present as foreign one's own opinion or claims (Viitso 2008: 320). The reported imperative (jussive) forms, as in example (12), are used to designate commands or requests originating from a third party (not the speaker).

2 Kehayov et al. (2011: 86) use the term deliberative question to denote a question where the response is expected to be directive. 
(14) tämmõn $k a \quad$ vólli

S/he:DAT also be.REP.IND.SG problem

's/he is also reported to have a problem' (Kettunen 1925: 67)

Here evidentiality is grouped under mood/modality. Crosslinguistically, however, the question whether evidentials should be treated under mood/modality or viewed separately from them, has been much debated (e.g., Palmer 2001, Thieroff 2010).

There are also studies that discuss ways of expressing modality by looking at a particular semantic domain. For example, Viitso (2014) discusses the expression of obligation, duty, and necessity (i.e., deontic modality) by means of various constructions. He argues that there are 11 such constructions, which can be distinguished on the basis of three components: (i) whether the EXPERIENCER is in the nominative or dative case, (ii) whether the predicate is pidìm 'must', pidìks 'should have', tūlda 'come', lä'd $d \tilde{o}$ 'go', vōlda 'be', or lìdõ 'will, shall', and (iii) whether the infinitive, supine, or participle of the main verb or the adverb vajag 'necessary' + an object occurs (see Viitso 2014: 212). Example (15) illustrates an instance of a construction containing the EXPERIENCER in the dative case, lìdõ in $3 \mathrm{Sg}$, and the debitive form of the main verb.

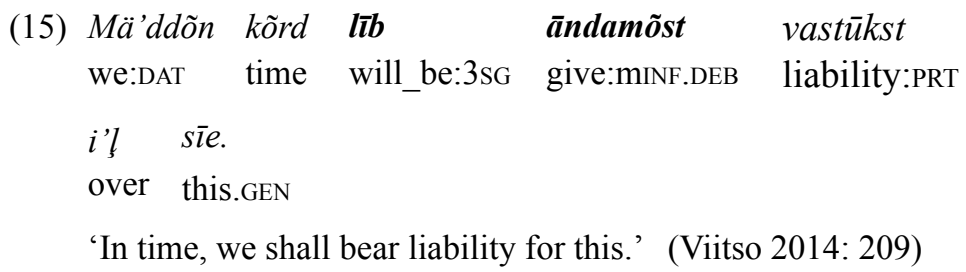

The debitive constructions, such as example (15), are also discussed by Wälchli (2000), who concentrates on the development of the Livonian and Latvian debitives. He concludes that the constructions show only partial parallel development (see more in Wälchli 2000: 207).

The expression of epistemic modality has been discussed as well, but only for the example of lìdõ used as copula or together with a past participle (e.g., Norvik 2015a). Other types of modalities have not yet been discussed in the literature. 


\subsubsection{Aspectual distinctions}

A well-known distinction in the field of aspect is the opposition between perfective and imperfective aspect (Comrie 1976: 3); occasionally, progressive aspect also is regarded as being of equal value (see Dahl 1985: 24-25). As the category of aspect in the Finnic languages, including Livonian, is not a fully grammaticalised category, the expression of aspectual distinctions in Livonian has been studied only a little. For example, Wälchli (2001) discusses the use of bounders in Livonian, i.e., verb particles (e.g., järā 'away'; see example 1) and prefixes (e.g., no-; see example 16). He claims that though bounders could be associated with aspectual distinctions (verb particles with imperfective-like and prefixes with perfective-like distinctions), their primary function is to express telicity or accomplishment/achievement (see more in Wälchli 2001: 420). The prefixes in Livonian are loans from Latvian. These are discussed in a separate study by F. de Sievers (1971a, 1971b).

$\begin{array}{lllll}\text { pois } & \text { nomagüb } & i ' l & \overline{1} \mathrm{e} & \text { un } \ldots \\ \text { boy } & \text { PX:sleep:3SG } & \text { over } & \text { night } & \text { and }\end{array}$

'the boy sleeps over night and...' (EDC)

A further option is to associate aspect with various phases of a situation and to distinguish between proximatives, ingressives, progressives, egressives, and retrospectives, which describe these various phases, i.e., phasal aspect (see more in Bhat 1999: 44, Erelt 2013: 77). In Livonian, the ways in which the various types of phasal aspect are expressed have not yet been discussed in the literature. It is only to some extent that Norvik (2015b) has studied resultativity ${ }^{3}$ in connection with participle constructions (see subsection 2.1.1). With respect to ingressivity (which denotes the beginning of an action), only the infinitive constructions containing akkõ 'seize, grab; begin' and irgõ 'begin' have been analysed (see Norvik et al. 2014).

\subsection{Nominal arguments}

In addition to the predicate, the other main grammatical functions subject, object, predicative complement, adverbial, and attribute - have

3 Resultativity can be associated with retrospectives that express the resulting state of a previous action (see e.g., Erelt 2013: 86). 
been described, though to varying extents. The following subsections (2.2.1 through 2.2.4) introduce the main findings presented in different works. Whereas the attribute may also be considered a grammatical function, newer approaches tend to discuss it together with the noun phrase (see e.g., ISK 2004). In this article as well, the behaviour of the attribute is described together with phrases (see section 3 ).

\subsubsection{Subject}

As typical of the Finnic languages in general, the prototypical subject in Livonian appears in the nominative case and agrees with the verb in person and number (example 17). In addition to the noun phrase $^{4}$, the infinitive form and quantity phrase also are mentioned as possible subjects (see Viitso 2008: 341). The fact that not only the object but also the subject shows case alternation was noted already by Sjögren and Wiedemann (1861a: 235-236), who pointed out that there are instances when it is hard for a foreigner to decide whether to use the nominative or the partitive case. According to Viitso (2008: 341), the partitive form of the subject denotes an undefined amount of something (example 18).

lapst mängabõd

child:PL play:3PL

'the children are playing' (Viitso 2008: 341)

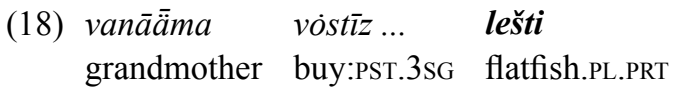

'grandmother ... bought some flatfish' (Viitso 2008: 341)

Sjögren and Wiedemann (1861a: 232) also describe the circumstances when the subject is omitted: (i) the personal pronoun may be omitted if the referent is clear from the personal ending, (ii) the clauses with a general referent cannot have a subject, e.g., võib lädo (can:3sG go:tiNF) 'one can go', (iii) the subject is not used with impersonal verbs, e.g., kīlmab (freeze:3sG) 'it is freezing'. Elliptical and defective clauses have not received much separate attention elsewhere. For comparison, Viitso (2008) only mentioned type (iii) in connection with presenting basic clause types (see also section 4 ).

4 Here noun phrase also stands for single words. 


\subsubsection{Object}

The syntactic behaviour of object in Livonian has been discussed by several researchers. The main reason for this is the well-known alternation of object cases, characteristic of Finnic languages in general. Sjögren and Wiedemann (1861a) already thoroughly described the alternation of object cases; there is also a separate study on object by T. Tveite (2004).

The main object cases in Livonian are the genitive and partitive, only rarely also the nominative. As explained by various authors (Tveite 2004, Viitso 2008), on the one hand, there are verbs that take only the partitive case, e.g., tie'nnõ jumāltõ (thank:tINF God:PRT) 'thank God', on the other hand, there are verbs that show genitive $\sim$ partitive (seldom nominative) alternation. The genitive case is used if the object is a person or a thing, expresses a definite amount of something and the verb conveys an action, which has been completed or will be completed, see example (15). Unlike in other Finnic languages, in Livonian the plural nominal object and the imperative object are in the genitive case (example 16). Although generally the partitive is used when negating the object (as in Estonian), the genitive case also is possible (see Viitso 2008: 341). The alternation of genitive and partitive objects in clauses with negated verbs is also common to Latvian (for more information, see Kalnača 2014: 56-57).

$$
\begin{array}{lllll}
\text { Ta } & m \bar{u} z & \text { engtš } & \text { laps } & \text { järā. } \\
\text { s/he } & \text { sell:PST.3SG } & \text { own:GEN } & \text { child:GEN away }
\end{array}
$$

'S/he sold his/her child.' (Viitso 2008: 341)

(20) Valā $\quad$ sie $\quad v i e$ 'd $\quad$ u'lzõ.
pour.IMP.2SG this.GEN $\quad$ water:GEN out
'Pour the water out.'

\subsubsection{Predicative complement}

According to Viitso (2008: 342), the predicative complement in Livonian occurs together with the verbs vō̄lda 'be', sōdõ 'get; become', iedõ 'remain; become', lìdõ 'will be' and answers the questions kis? 'who or what', mis? 'what', mingi? 'what kind' and mitsmõz 'which one'. This means that Viitso supports the broader definition of the predicative complement. For comparison, the 'be' -verb and 'become' -verbs are 
also regarded as possible linking verbs in Finnish (ISK 2004: 900), while in Estonian (EKG II: 55), the predicative complement is only associated with the 'be'-verb.

According to Viitso (2008: 342), the noun phrase and quantity phrase used as predicative complements convey the type of the subject referent (21) or similarity (22), and the adjective phrase expresses a property of the subject referent (23). In typological literature, example (21) is referred to as proper inclusion, example (22) as equation, and example (23) as attribution (see e.g., Payne 1997: 114). As follows, the term equation is used instead of similarity to describe example (22), as regarding it as similarity would lead astray.

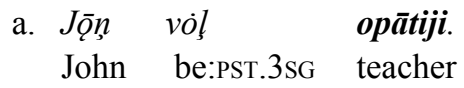
'John was a teacher.' (Viitso 2008: 342)

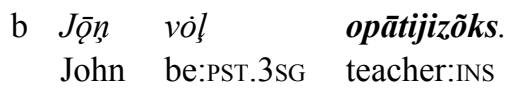
'John was a teacher [for some time].' (Viitso 2008: 342)

(22) Kuoštrõg um mi'n sindõkūož.

Kuoštrõg be.3sg I.GEN birthplace

'Kuoštrõg is my birthplace.' (Viitso 2008: 342)

$\begin{array}{lll}\text { (23) Läpš } & \text { um } & \text { rujā. } \\ \text { child } & \text { be.3sG } & \text { sick }\end{array}$

'The child is sick.' (Viitso 2008: 342)

With regard to the noun phrase and quantity phrase, the use of the nominative case for the predicative complement, as in example (21a) and (22), is said to denote an inherent or definite state or equation, whereas the instrumental case is claimed to indicate a temporary state, see example (21b) (Viitso 2008: 342). Instances such as (21b) can be seen as extensions of the translative case (for Livonian, the term instrumental is preferred) into copular clauses, which has taken place in Estonian and Livonian (Kont 1955: 168). The use of the instrumental case for conveying a temporary and non-essential character of a situation only affects predicate nouns (21b), leaving the predicate adjectives unaffected (cf. example 23) (see also Erelt and Metslang 2003: 167-168). For the use of adverbial of state in the essive, see Viitso (2016) in the present volume. 
In Estonian and Finnish, the distinction between totality vs. partiality is manifested also in the complement predicative (e.g., ISK 2004: 901, EKG II: 58). The case alternation of the predicative complement in Livonian, in turn, has not been discussed in previous works.

\subsubsection{Adverbial}

Viitso (2008: 342) explains the semantic functions of adverbials using the following terms: actor, possessor, experiencer (example 24), accompaniment, instrument, object of an activity (example 25), place (goal, location, and source), time, measure or amount, and manner. Most of these notions can be associated with what are known as semantic roles (see e.g., Andrews 2007, Payne 1997). In the same way that the inventory of semantic roles varies from author to author, there are also differences in what is included under a particular role. For instance, EXPERIENCER is typically used for living beings that are able to feel or perceive something, which is also the definition applied by Viitso in example (24). But instead of regarding ențšs vi'lst 'by one's own shadow' as the object of an activity in example (25), one could use the semantic role stimulus, which is used for something that causes a sensory feeling as in example (25) (see Luraghi and Parodi 2008: 170).

(24) Mi’nñ̃n um kīlma.

I:DAT be.3sg cold

'I'm cold.' (Viitso 2008: 342)

(25)

$\begin{array}{lllll}\text { Mis } & \text { sa } & \text { kärtad } & \text { entř } & \text { vi'lst. } \\ \text { what } & \text { you } & \text { be_afraid:2SG } & \text { own.GEN } & \text { shadow.ELA }\end{array}$

'Why are you afraid of your own shadow.' (Viitso 2008: 342)

Viitso also provides examples of different types of adverbials when describing the functions of cases in the chapter on morphology (see Viitso 2008: 326-329).

\section{Phrase structure}

With regard to phrases, i.e., noun phrases, adjective phrases (including gradation), adverbial phrases, quantity phrases, and adpositional phrases, the most attention has been devoted to the 
adpositional phrase. There is also a separate study by R. Grünthal, Finnic adpositions and cases in change (2003), in which he discusses the adpositional phrase in Livonian.

Finnic languages are famous for containing both prepositions as well as postpositions. This applies to Livonian, as well. Whereas postpositions typically demand a preceding noun to be in the genitive, prepositions may demand that the following noun be (i) in the genitive, e.g., $l e$ 'b mõtsā (through forest:GEN) 'through the forest', (ii) partitive, e.g., jedmõl suo'ddõ (before war:PRT) 'before the war', or (iii) instrumental case, e.g., pa vanāks (PREP old:INS) '[become] old' (Viitso 2008: 336). In his thesis, Grünthal explores whether the postpositional phrase can also contain a dative-marked constituent. He shows that although none of the postpositions demand that the preceding noun be in the dative case, occasionally a dative constituent can constitute a postpositonal phrase, as in example (26) (Grünthal 2003: 94-95, 108). It is possible that here we see a parallel with Latvian klat 'near', which requires the dative case. The other preposition used in a similar function is pie, which requires the genitive case. Semantically, the contact expressed by klāt is closer than that expressed by pie (Valts Ernštreits, p.c.).

$\begin{array}{lrll}\text { ta'm } & \text { ma'ggõn } & \text { se } \bar{a} r g a n & j u ̄ s \\ \text { s/he_be.3SG sleep:APP } & \text { this ox:DAT near } \\ \text { 's/he slept with the ox' } & \text { (Setälä 1953: 104) }\end{array}$

In connection with noun phrases, one can also consider the attribute (for treating the attribute as a separate grammatical function, see the comment in subsection 2.2), which is a modifier of a noun. The characteristics of attributes in Livonian have been discussed by Viitso (2008), who divides them into three groups depending on their part of speech; he also describes the agreement of attributes with their heads. These three groups are the following:

1. The attribute is an adjective, demonstrative, or ordinal; the corresponding attributes agree with their head in case and number, but if the head is in its dative or instrumental form, the attribute is in the singular or plural genitive depending on the number of the head, e.g., sürd lōjadõks (big:PL.GEN boat:PL.INS) 'with big boats'. The attribute can be in the genitive also if the head is in the inessive or elative form; the adessive or ablative head is usually preceded by the attribute in the inessive or elative, respectively. 
2. The attribute is a noun, pronoun, or demonstrative; depending on the number of possessors, the corresponding attribute appears in the singular or plural genitive form, e.g., laps $k \overline{\tilde{o}} r$ (child.gEN bicycle) 'child's bicycle' vs. lapst kỗr (child:PL.GEN bicycle) 'children's bicycle'.

3. The attribute is a predicative or adverbial phrase, e.g., pūstõ lä'bdi (wood:ELA shovel) 'wooden shovel'.

(Viitso 2008: 343)

The attributive use was also described by Sjögren and Wiedemann (1861a: 139), who pointed out that participle forms tend to be more commonly used with an attributive function than adjectives, e.g., sulātõmiz rīst (melting:GEN dish) > sulätõ b rīst (melt:PPrP dish) 'a dish for melting'. Viitso (2008: 323) only gives examples of the passive present participle used attributively in compound words, e.g., je'ltõbtuba a (live:Pprp_room) 'living room', while the Livonian-Estonian-Latvian dictionary also contains instances of a participle form and a noun written as two words, e.g., je'ltõ $\boldsymbol{b} i$ 'bbi (work:pprp horse) 'workhorse' (see Viitso and Ernštreits 2012: 89).

With regard to other phrases, Grünthal (2003: 177-185) analyses the translative-governing prepositional constructions containing the Latvian-originated $p a$. The structure of other phrases has not been commented on their own, but introduced together with other topics, e.g., when introducing parts of speech and their grammatical functions (see Viitso 2008: 325-336).

Viitso (2008) also describes the degrees of comparison. The comparative degree can be formed synthetically as is typical of the Finnic languages in general (e.g., vanā 'old' > vañimi 'older') or analytically by using the preposition jo (e.g., jo kìlma 'colder', in which case kìlma remains in its nominative form). For the superlative, the word ama 'the most' can be used with the comparative or the nominative form (ama vañimi 'the oldest' or amā kìlma 'the coldest') (Viitso 2008: 330). The analytical formation is argued to be very common, but it remains unclear what conditions the choice between the morphological and analytical constructions.

\section{Clause types and word order}

Viitso (2008) presents the following basic clause types for Livonian: (i) normal clauses (e.g., example 27; further divided into 4 subtypes), (ii) impersonal clauses (example 28), (iii) locative clauses (example 
29a), (iv) time and weather clauses, (v) possessive clauses, (vi) state clauses, (vii) resultative clauses, and (viii) debitive clauses (further divided into 7 subtypes). The subtypes of normal clauses are distinguished on the basis of their arguments: (i) subject and verb (example 27), b) subject, verb, and predicative, c) subject, verb, and object, d) subject, verb, and adverb (for debitive constructions, see subsection 2.1.2). (Viitso 2008: 343-344) For studying copular clauses in Livonian, Norvik (2014) makes a primary distinction between five clause types: predicate nominal, existential, locational, resultative, and possessive clauses, which enables her to explain not only the use of līdõ 'will be', but also sōdõ 'get; become' and $\bar{\imath} e d \tilde{o}$ 'remain; become' when occurring as simple predicates.

(27) Kik lōlab.

rooster sing:3sG

'The rooster is singing.' (Viitso 2008: 343)

$\begin{array}{lllll}\text { Lūomõd } & \text { ajāb } & \text { u'lzõ } & \text { nitõ } & \text { siemõ. } \\ \text { animal:PL.GEN } & \text { drive:3SG } & \text { out } & \text { pasture:ILL } & \text { eat:minF }\end{array}$

'Animals are driven out to pasture to eat.' (Viitso 2008: 343)

(29) a. Mõtsās um põ'ddiri.

forest:INE be.3sg elk.PL.PRT

'There are elk in the forest' (Viitso 2008: 343)

b. Põ'ddõrd attõ mõtsās.

elk.PL be.3PL forest:INE

'Elks are in the forest.' (personal knowledge)

For comparison, in Estonian a distinction is made between three main types of basic clauses: the normal clause, existential clause, and experiencer-possessive clause (EKG II: 14). The experiencer and possessive clauses can also be considered as separate, and the resultative clause can be added to this list of clause types, as well (see Erelt 2013). In Finnish, the primary distinction is between multifunctional clauses (the intransitive, transitive, and copular clauses) and special clauses (e.g., the existential clause, possessive clause, etc.) (see more in ISK 2004: 848). These distinctions depend partly on language-specific reasons, partly on how fine-grained of an approach is taken, and partly on the terms used. For example, Viitso (2008) presents example (29a) 
as an instance of a locative clause, but in EKG II, ISK (2004), and Erelt (2013) such cases are considered as existential clauses as they fulfil a presentative function by introducing participants to the discourse. An instance of a locative clause would be example (29b). See also Payne (1997: 123) for arguments in favour of regarding (29a) as an existential clause and (29b) as a locative clause.

The distinction between clause types is also related to word order. Normal clauses are unmarked basic clauses that have a nominative subject at the beginning (see example 27). The remaining clause types reveal some other word order, e.g., the impersonal clause has an object at the beginning (example 28), the existential clause (example 29a) begins with a locative adverbial.

The general rules for word order, however, have been commented on only by Sjögren and Wiedemann (1861a: 280-283). They discuss the order of the subject and verb in the declarative, interrogative, imperative as well as optative sentences, the position of the object in relation to the verb, and various other rules. For instance, in imperative and optative clauses, the subject tends to follow the verb; in the case of a periphrastic construction, the subject follows the auxiliary verb (Sjögren and Wiedemann 1861a: 280). Example (30) is an instance of an optative clause containing an auxiliary. In fact, the situation is similar in the case of complex clauses (a typologically well-known categorization distinguishes complement clauses, relative clauses, and adverbial clauses) that have been discussed only by Sjögren and Wiedemann (1861a). As the most recent description of Livonian word order is more than 150 years old, a contemporary description is more than needed. Furthermore, it should be noted that word order tendencies in subordinate clauses is one of the topics not described even by Sjögren and Wiedemann.

$$
\begin{aligned}
& \text { koks } \quad \text { ma } \\
& \text { if_bël vönd } \\
& \text { 'if I [only] were there' (Sjögren and Wiedemann 1861a: 280) }
\end{aligned}
$$

\section{Pragmatic meanings of sentences}

With regard to the pragmatic meanings of sentences, i.e., the purpose of their use, a distinction is usually made between four main sentence types: declarative, interrogative, imperative, and exclamative sentences. Estonian grammars also tend to include the optative sentence (e.g., 
EKG II). The optative sentence is mentioned separately by Sjögren and Wiedemann (1861a), as well (cf. section 4). These sentence types have not received separate attention in the case of Livonian, but some information can still be found, e.g., the rules for word order were discussed in connection with sentence types by Sjögren and Wiedemann (1861a) (see section 4), Metslang et al. (2015) also analyse polar questions in an article on negation, Kehayov et al. (2011) compare the use of the imperative in Estonian (Kihnu), Latvian, and Livonian interrogatives (see subsection 2.1.2). Therefore, the various sentence types require a study of their own.

Negation is also frequently discussed as part of the pragmatic meanings of sentences. A recent study by Metslang et al. (2015) gives a thorough overview of negation in Livonian with a typological background and provides an analysis of various negation strategies in Livonian concerning both clausal negation and non-clausal negation as well as several other aspects of negation (e.g., how negation can be reinforced). The main markers that are discussed in the article are (i) the negative auxiliaries that differ in mood and tense (e.g., the 3Sg present indicative form is $\ddot{a} b$, whereas the corresponding past form is $i z$ ), (ii) the negation particle $\ddot{a} p$, which occurs alone as an answer to a question (example 31), (iii) the particle mittõ, which reinforces negation if it occurs before a negative particle (example 32 ) and has been shown to mark constituent negation if it occurs elsewhere. (Metslang et al. 2015: $444,451)$

$$
\begin{array}{llll}
\text { Või } & \text { sa } & \text { magīzt } ?- & N \bar{a} . / \ddot{A p} . \\
\text { Q } & \text { you } & \text { sleep:PST:2SG - } & \text { Yes / No }
\end{array}
$$

'Did you sleep?' - 'Yes. / No.' (Metslang et al. 2015: 444)

(32) $m a$ mittõ äb nä sīnda

I NEG NEG.2SG see.CNG you.PRT

'I don't see you.' (Metslang et al. 2015: 451)

\section{Conclusions}

This article presented the main results of previous studies dealing with syntax-related issues in Livonian. It was shown that the main topics of syntax - the predicate and its arguments, the structure of phrases, word order, etc. - have been discussed in previous works, but to various 
extents. There are topics (e.g., adpositional phrases, negation, evidentiality), which have been at the focus of relatively recent studies, but there are also topics that have been discussed only by Sjögren and Wiedemann (1861a) more than 150 years ago (e.g., word order issues). All in all, the current situation concerning research into Livonian syntax is that the information is scattered between various sources (a reference grammar, grammar overviews, separate studies) and chapters (e.g., chapters on morphology may also contain information on syntax); what is more, these are written in different traditions using different terminology.

Thus, it can be concluded that there is a considerable amount of previous research to take into account, test, and draw parallels with when preparing the syntax chapter for the new Livonian reference grammar. Although the present article gives several examples, which reveal that the grammar authored by Sjögren and Wiedemann (1861a) is partly outdated, their work still provides information on several matters that have not been discussed elsewhere and that can be compared with newer data. A challenge related to this is to what extent one can hope to fill all the gaps. There are, for instance, many narratives and texts, but fewer interviews or free conversations. A separate question is how to find a balance between written and spoken language. Still, in any case, the new reference grammar will enable one to find information on syntax in a single source.

\title{
Acknowledgements
}

The study was supported by the projects IUT2-37 and Livonian grammar and databases financed by the Estonian Ministry of Education and Research.

\author{
Address: \\ Miina Norvik \\ Institute of Estonian and General Linguistics \\ University of Tartu \\ Jakobi 2-445 \\ 51014 Tartu, Estonia \\ E-mail: miina.norvik@ut.ee
}




\begin{abstract}
Abbreviations
1, 2, 3 - persons, APP - active past articiple, $\mathrm{CND}$ - conditional, $\mathrm{CNG}-$ connegative, DAT - dative, DEB - debitive, ELA - elative, GEN - genitive, ILL - illative, IMP - imperative, INE - inessive, INS - instrumental, JUSS jussive, mINF - M-infinitive, NEG - negative, PL - plural, PPP - passive past participle, PPrP - passive present participle, PREP - preposition, PRT partitive, PST - past, PTCL - particle, PX - prefix, Q - question particle, $\mathrm{SG}$ - singular, tINF - T-infinitive
\end{abstract}

\title{
References
}

Andrews, Avery D. (2007) [1985] "The major functions of the noun phrase". In Timothy Shopen, ed. Language typology and syntactic description. Vol. 1: Clause structure, 132-223. Cambridge: Cambridge University Press.

Bhat, Shankara D. N. (1999) The prominence of tense, aspect and mood (Studies in Language Companion Series 49). Amsterdam, Philadelphia: John Benjamins.

Bybee, Joan L. and Östen Dahl (1989) "The creation of tense and aspect systems in the languages of the world". Studies in Languages 13, 1, 51-103.

Bybee, Joan, Revere Perkins and William Paglicua (1994) The evolution of grammar: tense, aspect, and modality in the languages of the world. Chicago and London: University of Chicago Press.

Comrie, Bernard (1976) Aspect: an introduction to the study of verbal aspect and related problems (Cambridge Textbooks in Linguistics). Cambridge: Cambridge University Press.

Comrie, Bernard (1993) Tense. (Cambridge Textbooks in Linguistics). 2nd edn. Cambridge: Cambridge University Press.

Dahl, Östen (1985) Tense and aspect systems. Oxford, New York: Basil Blackwell.

de Haan, Ferdinand (2006) “Typological approaches to modality”. In William Frawley, ed. The expression of modality (The expression of cognitive categories 1), 27-70. Berlin and New York: Mouton de Gruyter.

de Sivers, Fanny (1971a) Die lettischen präfixe des livischen Verbs. Les prefixes lettons du verbe live. Paris.

de Sivers, Fanny (1971b) Die lettischen präfixe des livischen Verbs. Les prefixes lettons du verbe live. Wörterverzeichnis. Vocabulaire. Paris.

$\mathrm{EDC}=$ Estonian Dialect Corpus. Available online at $<\mathrm{http}: / / \mathrm{www}$. murre.ut.ee $>$. Accessed on 26.06. 2016.)

EKG II = Erelt, Mati, Reet Kasik, Helle Metslang, Henno Rajandi, Kristiina Ross, Henn Saari, Kaja Tael ja Silvi Vare (1993) Eesti keele grammatika II. Süntaks. Lisa: kiri. Trükki toimetanud Mati Erelt (peatoimetajana), Tiiu Erelt, Henn Saari, Ülle Viks. Tallinn: Eesti Teaduste Akadeemia Keele ja Kirjanduse Instituut.

Erelt, Mati (2013) Eesti keele lauseõpetus. Sissejuhatus. Öeldis (Tartu ülikooli eesti keele osakonna preprindid 4). Tartu: Tartu Ülikool. 
Erelt, Mati and Helle Metslang (2003) "Case Marking of the Predicative in Estonian". Linguistica Uralica, 39, 3, 166-174.

Grünthal, Riho (2003) Finnic adpositions and cases in change (Suomalais-Ugrilaisen Seuran toimituksia 244). Helsinki: Suomalais-Ugrilainen Seura.

Holvoet, Axel (2001) "Impersonals and passives in Baltic and Finnic". In Östen Dahl and Maria Koptjevskaja-Tamm, eds. The Circum-Baltic Languages, vol. 2: Grammar and Typology (Studies in Language Companion Series 55), 363-389. Amsterdam and Philadelphia: John Benjamins.

ISK = Hakulinen, Auli, Maria Vilkuna, Riitta Korhonen, Vesa Koivisto, Tarja Riitta Heinonen, Irja Alho (2004) Iso suomen kielioppi (Suomalaisen Kirjallisuuden Seuran Toimituksia 950). Helsinki: Suomalaisen Kirjallisuuden Seura.

Kalnača, Andra (2014) A typological perspective on Latvian grammar. Warsaw, Berlin: De Gruyter Open. Available online at $<$ http://www.degruyter.com/viewbooktoc/product/449849>. Accessed on 26.04. 2016.)

Kehayov, Petar, Liina Lindström and Ellen Niit (2011) "Imperative in interrogatives in Estonian (Kihnu), Latvian and Livonian”. Linguistica Uralica 47, 2, 81-93.

Kehayov, Petar, Helle Metslang and Karl Pajusalu (2012) "Evidentiality in Livonian". Linguistica Uralica 48, 1, 41-54.

Kettunen, Lauri (1925) Untersuchung über die livische Sprache, I: Phonetische Einführung. Sprachproben (Acta et Commentationes Universitatis Dorpatensis. B. VIII. 3). Tartu.

Kettunen, Lauri (1938) Livisches Wörterbuch mit grammatischer Einleitung. Helsinki: Suomalais-Ugrilainen Seura.

Klaas-Lang, Birute and Miina Norvik (2014) "Balti areaali tüpoloogilisi sarnasusi morfosüntaksi valdkonnas”. Keel ja Kirjandus 8-9. 590-608.

Kont, Karl (1955) “Translatiivist läänemeresoome keeltes ja mordva ning lapi keeles”. Emakeele Seltsi aastaraamat, I. Tallinn

Krautmane, Ērika (2010) Kuramaa liivi keele kõneviiside süsteem eesti ja läti keele taustal. Unpublished Master thesis. Tartu: Tartu Ülikool.

Laanest, Arvo (1975) Sissejuhatus läänemeresoome keeltesse. Tallinn: Eesti NSV Teaduste Akadeemia.

Luraghi, Silvia, Claudia Parodi (2008) Key terms in syntax and syntactic theory. New York: Continuum.

Mägiste, Julius (2006). Muistoja Liivinrannasta: liivin kieltä Ruotsista (SuomalaisUgrilaisen Seuran Toimituksia 250). Helsinki: Suomalais-Ugrilainen Seura.

Metslang, Helle, Karl Pajusalu and Tiit-Rein Viitso (2015) "Negation in Livonian”. In Matti Miestamo, Anne Tamm and Beáta Wagner-Nagy, eds. Negation in Uralic languages (Typological Studies in Language 108), 433-456. Amsterdam: John Benjamins.

Narrog, Heiko (2012) Modality, Subjectivity, and Semantic Change: A Cross-Linguistic Perspective. Oxford: Oxford University Press.

Norvik, Miina (2014) "Change-of-state predicates and their use in expressing the future: the case of Livonian". Eesti ja soome-ugri keeleteaduse ajakiri. Journal of Estonian and Finno-Ugric Linguistics 5 (1), 117-148. 
Norvik, Miina (2015a) Future time reference devices in Livonian in a Finnic context (Doctoral thesis). Tartu: University of Tartu Press.

Norvik, Miina (2015b) "The past participle constructions LEE(NE)- + PTCP and SAA- + PTCP as future time reference devices: the example of Livonian against a Southern Finnic background". Journal de la Société Finno-Ougrienne 95, 201-236.

Norvik, Miina, Piret Piiroja and Külli Prillop (2014) "Verbi "hakkama" tähendusnihked eesti ja liivi keeles". Keel ja Kirjandus 8-9, 631-647.

Palmer, Frank R. (2001) Mood and Modality (Cambridge Textbooks in Linguistics). Cambridge: Cambridge University Press.

Payne, Thomas E. (1997) Describing Morphosyntax: A Guide for Field Linguists. Cambridge: Cambridge University Press.

Setälä, Eemil Nestor (1953) Näytteitä liivin kielestä (Mémoires de La Société FinnoOugrienne 106). Helsinki: Suomalais-Ugrilainen Seura.

Sjögren, Andreas Johann and Ferdinand Johann Wiedemann (1861a) Joh. Andreas Sjögren's Livische Grammatik nebst Sprachproben. Joh. Andreas Sjögren's Gesammelte Schriften. Band II. Theil I. St. Petersburg.

Sjögren, Andreas Johann and Ferdinand Johann Wiedemann (1861b) Joh. Andreas Sjögren's livisch-deutsches und deutsch-livisches Wörterbuch. Joh. Andreas Sjögren's Gesammelte Schriften. Band II. Theil II. St. Petersburg.

Thieroff, Rolf (2010) "Moods, moods, moods". In Björn Rothstein and Rolf Thieroff (eds.), Mood in the languages of Europe (Studies in Language Companion Series 120), 1-29. Amsterdam: John Benjamins.

Tveite, Tor (2004) The case of the object in Livonian: a corpus based study (Castrenianumin toimitteita 62). Helsinki: Finno-Ugrian Society.

$\overline{\mathrm{UT}}=\overline{\mathrm{Uz}}$ Testament (1942). Helsinki.

Viitso, Tiit-Rein (2008) Liivi keel ja läänemeresoome keelemaastikud. Tallinn: Eesti Keele Sihtasutus.

Viitso, Tiit-Rein (2014) "Expressions of obligation, duty, and necessity in Livonian". Eesti ja soome-ugri keeleteaduse ajakiri. Journal of Estonian and Finno-Ugric Linguistics 5 (1). 193-214.

Viitso, Tiit-Rein (2016) “The essive in Livonian”. Eesti ja soome-ugri keeleteaduse ajakiri. Journal of Estonian and Finno-Ugric Linguistics 7 (1). 145-175.

Viitso, Tiit-Rein and Valts Ernštreits (2012) Līvõkiel-ēstikiel-lețkīel sõnārōntõz. Liivi-eesti-läti sõnaraamat. Lībiešu-igauņu-latviešu vārdnīca. Tartu, Rīga: Tartu Ülikool, Latviešu valodas aǵentūra.

Wälchli, Bernhard (2000) "Infinite predication as a marker of evidentiality and modality in the languages of the Baltic region". Sprachtypologie und Universalienforschung 53, 2, 186-210.

Wälchli, Bernhard (2001) "Lexical evidence for the parallel development of the Latvian and Livonian verb particles". In Östen Dahl and Maria KoptjevskajaTamm, eds. Circum-Baltic languages: Typology and contact, vol. 2: Grammar and Typology (Studies in Language Companion Series 55), 413-442. Amsterdam and Philadelphia: John Benjamins. 
Kokkuvõte. Miina Norvik: Liivi keele süntaksi uurimine: varasemad tulemused ning eesseisvad ülesanded. Artikli eesmärgiks on esitleda peamisi liivi keele süntaksi uurimisel saadud tulemusi esimese teadusliku grammatika ilmumisest 1861. aastal kuni tänapäevani ning selgitada uue grammatika kirjutamisega seotud ülesandeid. Kuigi liivi keele süntaksi uurimine on hoogustunud alles viimastel aastakümnetel, on süntaksi põhiküsimusi varemalt käsitletud vähemalt põgusalt. On nii teemasid, mis on alles hiljuti tähelepanu keskmesse tõusnud (nt tuleviku, modaalsuse, eituse väljendamine), kuid on ka teemasid, mida on viimati käsitletud üle 150 aasta tagasi (nt sõnajärg) või mida pole üldse uuritud (nt osaöeldistäide, sõnajärg kõrvallauses). Peamiste eesseisvate ülesannetena nähaksegi varasemate uurimistulemuste koondamist uude grammatikasse; vajadusel nende ühtlustamist ja kontrollimist, kuna uurimused on kirjutatud eri aegadel ning traditsioonis; ning varasemas uurimuses esinevate lünkade täitmist.

Märksõnad: liivi keel, süntaks, grammatika, predikaat, nominaalsed argumendid, lausetüübid

Kubbõvõttõks. Miina Norvik: Līvõ kīel sintaks tuņšlimi: jedlõmizt rezultātõd ja tulbizt ilzandõkst. Kēra võttõksõks um līvõ kīel sintaks tuņšlimiz pämizt rezultātõd klīerimi ežmiz tieudliz grammatik ulzõ āndamizõst 1861. āigastõn tämpiz sọņõ ja sel̦tõ tulbiži ilzandõkši ūd grammatik kēratimiz pierāst. Koks kil līvõ kīel sintaks tuņšlimi um võttõn jūontõ set perrizt āigastkimmõd āigal, sintaks pūojkizzimiži um van̦ţõltõd jõvā vaŗīmõld, amā veitõm lītõld. Nei ātõ tematõd, mis ātõ perīst kõrdõ vaņţõltõd jemīṇ ku 150 āigastõ tāgižpēḍõn (ngț. sõnākỗrda) agā ka selllizt, mis äb ūotõ vaņţõltõd. Nei siz pämizt tulbizt ilzandõd ātõ vaŗīmõd tuņšlimiz rezultātõd kubtimi ūd grammatik pierāst, nänt lebbõ vaņţlimi, îtiztimi ja vaŗīmiz tuņšlimiz ōkõd tätami. 